\title{
Assessment of Resistance of Tubers of Potato Cultivars to Phytophthora erythroseptica and Pythium ultimum
}

\author{
Bacilio Salas, Gary A. Secor, R. J. Taylor, and Neil C. Gudmestad, Department of Plant Pathology, North Dakota \\ State University, Fargo 58105
}

\begin{abstract}
Salas, B., Secor, G. A., Taylor, R. J., and Gudmestad, N. C. 2003. Assessment of resistance of tubers of potato cultivars to Phytophthora erythroseptica and Pythium ultimum. Plant Dis. 87:91-97.

Tubers of 34 potato cultivars were examined for their susceptibility to infection by zoospores of Phytophthora erythroseptica and mycelia of Pythium ultimum. Incidence of infected tubers (\%) and penetration of rot $(\mathrm{mm})$ were the parameters used to determine the susceptibility of each cultivar. Tubers of cv. Atlantic appeared to have some resistance to infection and colonization by Phytophthora erythroseptica. Cvs. Russet Norkotah and Snowden were the most susceptible to infection by $P$. erythroseptica. Snowden was found to be highly susceptible to $P$. erythroseptica, but it was the most resistant to Pythium ultimum. Cvs. FL-1625 and FL-1867 also were less susceptible to P. ultimum than the other cultivars. Cvs. Superior, Itasca, and Dark Red Norland were the most susceptible to P. ultimum. Cultivar susceptibility should be considered when making disease management decisions, particularly in fields where these soilborne diseases are a recurring problem.
\end{abstract}

Additional keywords: control, epidemiology, leak, pink rot, Solanum tuberosum

Pink rot of potato (Solanum tuberosum L.) caused by Phytophthora erythroseptica Pethybr. and leak caused by Pythium ultimum Trow are two important soilborne diseases of potato in the United States (32). The name pink rot describes the diagnostic pink color that appears in infected tuber tissue when cut and exposed to air for 20 to 30 min $(12,24)$. The common disease name of leak is descriptive of the exudation of water droplets from the blackish, soft watery breakdown of tissue of infected tubers $(2,16)$. These diseases can cause severe yield losses in fields and in storage facilities $(1,16,32)$. In the United States, levels of pink rot infection in fields ranged from 10 to $75 \%(1,4,8)$, and often tubers in infected areas or the entire field may not be harvested. Tubers infected with Phytophthora erythroseptica usually are found in wet, low-lying areas during harvest, and symptom development occurs soon after tubers are placed in storage facilities $(1,3,32)$. The leak pathogen also can cause seed-piece decay after planting (16) and kill seedlings from true potato seed (24).

Corresponding author: N. C. Gudmestad E-mail: Neil.gudmestad@ndsu.nodak.edu

Current address of B. Salas: Department of Plant Pathology, University of Minnesota, St. Paul 55108.

Accepted for publication 6 September 2002.

Publication no. D-2002-1118-02R

(C) 2003 The American Phytopathological Society
Infection of tubers by $P$. erythroseptica generally occurs via stolons $(10,21,27)$; however, tubers also can be infected by zoospores of $P$. erythroseptica through tuber eyes (29) and wounded tubers (31). Pythium ultimum is incapable of penetrating the undamaged skin of the tuber (14). Thus, infections by the leak pathogen always start at cuts and wounds, and only occasionally through the stem end (1).

Studies on cultivar susceptibility to Phytophthora erythroseptica and Pythium ultimum are scarce and most are outdated, involving potato cultivars no longer in production. Most studies on cultivar susceptibility to pink rot and leak involve one pathogen or the other and do not evaluate susceptibility to both diseases. In studies involving pink rot, Cairns and Musket (6) evaluated 51 cultivars and found that all were susceptible. Similarly, Jones (17) found that none of the eight cultivars he tested were resistant. Other studies have identified that cultivars exhibited various levels of susceptibility. Goss (12), reported that cvs. Irish Cobbler (6\%) and Kasota $(10 \%)$ had a lower incidence of infection than cvs. Warba (46\%) and Pawne (42\%). Fernandez-Northcote et al. (10) reported that tubers of only four clones were found to be resistant to pink rot after screening 13 cultivars and 242 native clones from Peru. Lennard (20) found that some cultivars were more susceptible than others. More recently, Stack et al. (33) noted that differences in cultivar susceptibility may not be significant enough to affect pink rot management. Peters and Sturz (25) re- ported that plantlets of cvs. Butte and Russet Burbank were the least susceptible, and those of Goldrush and Yukon Gold were the most susceptible. Regarding the susceptibility of potato tubers to the leak pathogen, Jones (16) reported that none of the 15 potato cultivars grown in British Columbia, Canada was resistant to leak. Hawkins (13) found that incidence of leak in cultivars can range from 0 to $91 \%$. Priou et al. (28) concluded that some cultivars were more susceptible than others to infection by Pythium aphanidermatum, the leak pathogen in tropical areas.

There is little information on the levels of resistance to the pink rot and leak pathogens of the potato cultivars currently grown in the United States; therefore, the main objective of this study was to assess the reaction of tubers of 35 cultivars to infection by zoospores of Phytophthora erythroseptica and mycelia of Pythium ultimum. Preliminary reports of this research have been published $(29,30)$.

\section{MATERIALS AND METHODS}

Potato cultivars, cultivation, harvest, and pre-inoculation handling. A total of 34 commercial potato cultivars (Table 1) were obtained from seed potato producers in North Dakota (ND), Minnesota (MN), or private companies. Whole or cut seed tubers were used for planting. All cultivars were produced in single rows $(30 \mathrm{~m})$ in field plots with center pivot irrigation in McLeod (ND) in 1998, in Glyndon (MN) in 1999, and in Dawson (ND) in 2000. Cultural practices during the growing season were those recommended for the production of potato in the Red River Valley. Tubers were harvested at maturity, visually inspected for pink rot and leak symptoms, and placed in a room at $15^{\circ} \mathrm{C}$ and $90 \%$ relative humidity for 2 weeks to promote wound healing. Thereafter, tubers of all cultivars were stored at $10^{\circ} \mathrm{C}$ for 2 to 3 months before inoculations. Disease-free tubers (140 to $190 \mathrm{~g}$ ) were acclimated to room temperature $\left(20\right.$ to $24^{\circ} \mathrm{C}$ ) 2 to 3 days prior to inoculations. No natural infections of pink rot or leak were observed in any year of the study. Preliminary studies showed that the frequency of infection by Phytophthora erythroseptica in surface sterilized tubers with $0.5 \% \mathrm{NaOCl}$ and non-surface-sterilized tubers were similar $(P=0.05)$. Therefore, tubers used for inoculations were not surface sterilized or washed prior to inoculation. Tubers used 
for inoculation with $P$. erythroseptica had the apical and at least one lateral eye free of soil, and those used for inoculation with Pythium ultimum had an intact periderm.

Pathogen isolates. Phytophthora erythroseptica isolates PR-347 (31) from Minnesota and PE-02 obtained in 1997 from an infected tuber from Carrington, ND were used to evaluate levels of resistance to pink rot. Isolates 153-7 and Py-HS of Pythium ultimum obtained in 1997 from infected tubers from Idaho and North Dakota, respectively, were used to evaluate resistance to leak. All isolates were identified based on described morphological characteristics $(34,35)$. Inoculations were made on freshly wounded Russet Burbank tubers with colonized agar plugs of the isolates. These preliminary studies showed that all isolates were highly pathogenic. Pathogenicity of all isolates was maintained every year through inoculation to Russet Burbank tubers and re-isolation on water agar culture plates.

Inoculations with Phytophthora erythroseptica. A method similar to that reported by Vujicic and Colhoun (36) was followed to obtain zoospores of $P$. erythroseptica. However, clarified V8 juice agar and clarified V8 juice broth were used instead of pea extract. Clarified V8 juice agar contained $100 \mathrm{ml}$ of clarified V8 juice, $15 \mathrm{~g}$ of agar, and $900 \mathrm{ml}$ of deionized distilled water. A stock of clarified V8 juice broth contained: $100 \mathrm{ml}$ of $\mathrm{V} 8$ juice filtered through four layers of cheesecloth, and $900 \mathrm{ml}$ of deionized distilled water. To obtain mycelial mats of $P$. erythroseptica, three mycelial disks ( $5 \mathrm{~mm}$ in diameter) of the pathogen grown on clarified V8 juice agar for 3 days were placed on each glass petri dish $(9 \mathrm{~cm})$ or plastic petri dish $(8.5$ $\mathrm{cm}$ ), flooded with $10 \mathrm{ml}$ of autoclaved clarified V8 broth, and incubated in darkness at room temperature $\left(20\right.$ to $24^{\circ} \mathrm{C}$ ) for 3 days. To induce sporangia formation, the clarified V8 juice broth was discarded, and replaced with a filtered and autoclaved soil extract (100 $\mathrm{g}$ of soil from potato field in $900 \mathrm{ml}$ of deionized water) at $10 \mathrm{ml} /$ petri plate, after rinsing the mycelial mats two to three times with sterile deionized water. These cultures were further incubated for 36 to $48 \mathrm{~h}$ under continuous light in an incubator $\left(20 \pm 1{ }^{\circ} \mathrm{C}\right)$ with eight lamps (Sylvania F20T12/CW). Finally, to induce the release of zoospores, cultures were chilled at $10 \pm 1^{\circ} \mathrm{C}$ for $1 \mathrm{~h}$ and rewarmed at room temperature $\left(20\right.$ to $\left.24^{\circ} \mathrm{C}\right)$. Abundant zoospore release occurred within 15 to 25

Table 1. Potato cultivars tested for their reaction to Phytophthora erythroseptica and Pythium ultimum ${ }^{\mathrm{a}}$

\begin{tabular}{|c|c|c|c|}
\hline Cultivars & Parentage & Release & Maturity group \\
\hline \multicolumn{4}{|l|}{ Red cultivars } \\
\hline Dark Red Norland & Clone from Red Norland & ? & Early \\
\hline La Rouge & LA02-5 (LaSoda $\times$ Progress) self & 1962 & Medium \\
\hline NorDonna & ND206-1R × ND821-6R & 1995 & Medium \\
\hline Red LaSoda & Triumph $\times$ Katahdin & 1953 & Main season \\
\hline Norland & Redkote $\times$ ND626 & 1957 & Early \\
\hline Red Pontiac & Triumph $\times$ Katahdin & 1945 & Late \\
\hline Viking & Nordak $\times$ Redskin & 1963 & Main season \\
\hline \multicolumn{4}{|l|}{ Russet cultivars } \\
\hline Goldrush & ND450-3Russ $\times$ Lemhi Russet & 1992 & Medium \\
\hline Liberty Russet & Somaclone of Lemhi Russet & 2000 & Medium late \\
\hline Russet Burbank & Early Rose $\times$ ? & 1914 & Late \\
\hline Russet Burbank-NL & Russet Burbank-GMO & 1995 & Late \\
\hline Russet Burbank-NLLR & Russet Burbank-GMO & ? & Late \\
\hline Russet Norkotah & ND9526-4Russ $\times$ ND9687-5Russ & 1987 & Medium-early \\
\hline Ranger Russet & Butte $\times$ A6595-3 & 1991 & Full season \\
\hline \multicolumn{4}{|l|}{ White cultivars } \\
\hline Atlantic & Waseon $\times$ B5141-6 (Lenape) & 1976 & Medium \\
\hline FL-1207 & $\ldots{ }^{b}$ & $\ldots$ & $\ldots$ \\
\hline FL-1533 & $\ldots$ & $\ldots$ & $\ldots$ \\
\hline FL-1625 & $\ldots$ & $\ldots$ & $\ldots$ \\
\hline FL-1831 & $\ldots$ & $\ldots$ & $\ldots$ \\
\hline FL-1833 & $\ldots$ & $\ldots$ & $\ldots$ \\
\hline FL-1867 & $\ldots$ & $\ldots$ & $\ldots$ \\
\hline FL-1879 & $\ldots$ & $\ldots$ & $\ldots$ \\
\hline FL-1900 & $\ldots$ & $\ldots$ & $\ldots$ \\
\hline Itasca & MN304.72-10 × ND58-3 & 1994 & Medium \\
\hline Kennebec & B127 × USDA X96-56 & 1948 & Medium \\
\hline LaChipper & Cayuga $\times$ Green Mountain & 1962 & Medium \\
\hline Norchip & ND4731-1 × M5009-2 & 1968 & Medium early \\
\hline NorValley & Norchip $\times$ ND860-2 & 1996 & Medium \\
\hline Pike & Allegany $\times$ Atlantic & 1995 & Medium \\
\hline Shepody & Bake-King $\times$ F58050 & 1980 & Medium late \\
\hline Shepody-NL & Shepody - GMO & $?$ & Medium late \\
\hline Snowden & B5141-6 (Lenape) $\times$ Wischip & 1990 & Full season \\
\hline Superior & USDA X96-56 × MN59.44 & 1961 & Early \\
\hline Yukon Gold & W5279-4 $\times$ Norgleam & 1980 & Medium \\
\hline
\end{tabular}

${ }^{a}$ Information obtained from Love (22) and University of Maine.

${ }^{\mathrm{b}}$ Information for Frito-Lay (FL) cultivars not available for public disclosure. min. A hemacytometer was used to obtain an inoculum concentration of $2 \times 10^{4}$ zoospores $\mathrm{ml}^{-1}$. Zoospore suspension was chilled $\left(8\right.$ to $\left.10^{\circ} \mathrm{C}\right)$ until inoculations were made within 10 to $60 \mathrm{~min}$. Before inoculations, tubers were placed in plastic moist chambers $(33 \mathrm{~cm}$ long by $24 \mathrm{~cm}$ wide by $12 \mathrm{~cm}$ high) lined at the bottom with plastic canvas mesh 3 . Each tuber was inoculated by placing a single drop of inoculum (10 $\mu \mathrm{l}$; approximately 200 zoospores) on each of the three apical eyes of tubers (one apical plus two next laterals). Control tubers were inoculated only with sterile distilled water. After inoculations, tubers were covered with two layers of wet paper towels before closing the moist chambers to maintain high humidity, thereby promoting infection. All inoculated tubers in moist chambers were incubated in darkness at room temperature $\left(20\right.$ to $\left.22^{\circ} \mathrm{C}\right)$ for 10 to 12 days.

Inoculations with Pythium ultimum. All tubers were wounded on one side before inoculations. The wounding procedure involved the removal of a disc of periderm tissue ( $5 \mathrm{~mm}$ in diameter by $1 \mathrm{~mm}$ deep) cut with a No. 2 cork borer from an area near the middle of one side of each tuber. Inoculum of $P$. ultimum was prepared by growing the isolates on modified V8 juice agar $\left(100 \mathrm{ml}\right.$ of $\mathrm{V} 8$ juice, $1.25 \mathrm{~g}$ of $\mathrm{CaCO}_{3}$, and $900 \mathrm{ml}$ of water) for $48 \mathrm{~h}$. One $P$. ultimum-colonized agar plug ( 5 by $3 \mathrm{~mm}$ ) cut from the colony margin was placed on the freshly wounded tuber tissue. Control tubers were inoculated with modified V8 juice agar plugs. The inoculated tubers were placed in plastic moist chambers as described above and were incubated in darkness at room temperature $\left(20\right.$ to $\left.22^{\circ} \mathrm{C}\right)$ for 6 days.

Disease assessment. Development of pink rot symptoms in tubers was examined 10 to 12 days after inoculations with Phytophthora erythroseptica, whereas development of leak symptoms was examined 6 days after inoculation with Pythium ultimum. Inoculated tubers were removed from moist chambers, sliced in half lengthwise through the inoculation point or points, and covered with moist paper towels to enhance the development of the pink discoloration diagnostic for pink rot and the watery blackish discoloration characteristic of leak. The number of tubers showing symptoms of pink rot or leak was recorded $30 \mathrm{~min}$ after cutting. Incidence of pink rot or leak rot was calculated as (number diseased tubers/number of inoculated tubers $) \times 100$. To determine pink rot and leak severity, the maximum width (W) and depth (D) of rot from the inoculation point were measured, then penetration of rot was calculated using the formula reported by Lapwood et al. (19): Penetration $=(\mathrm{W} / 2+[\mathrm{D}-5]) / 2$.

Experimental design and data analysis. A factorial of cultivar by isolate (35 by 2 ) experiment was arranged in a com- 
pletely randomized design with four replicates per cultivar. A replicate consisted of a set of 10 tubers per cultivar. Ten noninoculated tubers per cultivar served as controls. Two experiments for each isolate were conducted in the first year (1998), but only one experiment per isolate was conducted in 1999 and 2000. All 35 cultivars were not included in each year of the study. Cultivars were grouped based on the appearance of the skin as russets, reds, or whites for data analysis. All data were subjected to analysis of variance (PROC GLM, SAS). Pink rot or leak did not develop in tubers used as the control; therefore, these data were not included in the statistical analysis. Data from 3 years were pooled after testing the homogeneity of error mean squares (11) and analyzed as combined experiments as outlined by Carmer et al. (7). The relationship between pink rot incidence and severity and between leak incidence and severity were analyzed with Pearson's correlation test to determine the strength of the correlation between these variables. For this, only data for cultivars that were tested for a minimum of 2 years were included.

\section{RESULTS}

Assessment of incidence and severity of pink rot. Differences on incidence of infection among the potato cultivars to Phytophthora erythroseptica were highly significant (reds, $P<0.001$; russets, $P=$ 0.029 ; and whites, $P<0.001$ ). The effect of isolate and the interaction of isolatecultivar was not significant (Table 2). Among the red cultivars, Viking (78\%) and Red LaSoda (73.6\%) had the highest incidence of pink rot-infected tubers, whereas Norland $(52.2 \%)$ and NorDonna $(51.6 \%)$ had the fewest pink rot-infected tubers (Table 3; Fig. 1). Among the russet cultivars, Russet Norkotah $(88.1 \%)$ and Liberty Russet $(82.5 \%)$ had the highest incidence of pink rot and, in contrast, Russet Burbank (50.1\%) and Ranger Russet $(43.3 \%)$ had the lowest incidence of pink rot-infected tubers (Table 3; Fig. 1). Among the white cultivars, Snowden (85.3\%), FL-1207 (76.9\%), Kennebec (76.3\%), FL-1867 (74.8\%), and ShepodyNL $(74.7 \%)$ had the highest incidence of pink rot-infected tubers, whereas cultivars Atlantic (31.6\%) and FL-1900 (23.4\%) had the lowest (Table 3). Pink rot severity values in red, russet, and white cultivars were not significantly different (Table 3 ).
Assessment of the association incidence and severity of pink rot. The relationship between incidence and severity of pink rot in red cultivars was highly significant $(r=0.8, P=0.002)$. Plotting of paired values of incidence and severity of pink rot in red cultivars showed that cultivars such as Viking and Red LaSoda had a high incidence of pink rot and rotted more extensively, whereas cultivars such as Nordonna and Norland had low incidence of pink rot and rotted less extensively (Fig. 1). Incidence and severity values of pink rot in white and russet cultivars were not correlated significantly; however, there were cultivars with high incidence of infected tubers and extensive rotting of tuber tissue (Russet Norkotah), and cultivars with a low incidence of pink rot and low tuber rot severity (Atlantic) (Fig. 1).

Assessment of incidence of leak. The combined analysis of data of leak incidence showed that differences in the incidence of infection by the leak pathogen among the red and russet cultivars were not significant (Table 4). In contrast, differences in the incidence of leak infection among white cultivars were highly significant $(P=0.001$; Table 4). Cvs. Superior (97.3\%), LaChipper (96.9\%), FL-

Table 2. Combined analysis of variance of severity and incidence of pink rot caused by Phytophthora erythroseptica in 34 potato cultivars ${ }^{\text {a }}$

\begin{tabular}{|c|c|c|c|c|c|c|c|c|c|}
\hline \multirow[b]{2}{*}{ Sources of variation } & \multirow[b]{2}{*}{$\mathbf{D F}^{\mathbf{b}}$} & \multicolumn{4}{|c|}{ Severity } & \multicolumn{4}{|c|}{ Incidence } \\
\hline & & SS & MS & $F$ value & $P R>F$ & SS & MS & $F$ value & $P R>F$ \\
\hline \multicolumn{10}{|l|}{ Red cultivars } \\
\hline Year & $1(2)$ & $1,161.05$ & $1,161.05$ & $\ldots$ & $\ldots$ & $6,716.23$ & $3,358.12$ & $\ldots$ & $\ldots$ \\
\hline Rep (year) & $6(9)$ & 91.73 & 15.29 & $\ldots$ & $\ldots$ & $1,574.55$ & 174.95 & $\ldots$ & $\ldots$ \\
\hline Cultivarc & $6(6)$ & 126.13 & 21.02 & $0.60 \mathrm{NS}$ & 0.726 & $14,728.25$ & $2,454.71$ & $9.52^{* *}$ & 0.001 \\
\hline Isolate $^{\mathrm{d}}$ & $1(1)$ & 634.02 & 634.02 & $15.77 \mathrm{NS}$ & 0.157 & $14,307.90$ & $14,307.90$ & $3.96 \mathrm{NS}$ & 0.185 \\
\hline Cultivar $\times$ isolate $\mathrm{e}^{\mathrm{e}}$ & $6(6)$ & 367.75 & 61.29 & $1.31 \mathrm{NS}$ & 0.377 & 732.44 & 122.07 & $0.43 \mathrm{NS}$ & 0.847 \\
\hline Year $\times$ cultivar & $6(11)$ & 210.81 & 35.14 & $0.75 \mathrm{NS}$ & 0.633 & $2,837.38$ & 257.94 & $0.90 \mathrm{NS}$ & 0.569 \\
\hline Year $\times$ isolate & $1(2)$ & 40.20 & 40.20 & $\ldots$ & $\ldots$ & $7,225.23$ & $3,612.62$ & $\ldots$ & $\ldots$ \\
\hline Year $\times$ cultivar $\times$ isolate & $6(11)$ & 281.36 & 46.89 & $\ldots$ & $\ldots$ & $3,156.83$ & 286.99 & $\ldots$ & $\ldots$ \\
\hline Error & $78(111)$ & $1,131.28$ & 14.50 & $\ldots$ & $\ldots$ & $29,398.37$ & 264.85 & $\ldots$ & $\ldots$ \\
\hline Total & $111(159)$ & $4,044.31$ & $\ldots$ & $\ldots$ & $\ldots$ & $79,368.74$ & $\ldots$ & $\ldots$ & $\ldots$ \\
\hline \multicolumn{10}{|l|}{ Russet cultivars } \\
\hline Year & $1(2)$ & $2,495.56$ & $2,495.56$ & $\ldots$ & $\ldots$ & $6,978.76$ & $3,489.38$ & $\ldots$ & $\ldots$ \\
\hline Rep (year) & $6(9)$ & 104.43 & 17.41 & $\ldots$ & $\ldots$ & $2,111.89$ & 234.66 & $\ldots$ & $\ldots$ \\
\hline Cultivar ${ }^{\mathrm{c}}$ & $6(6)$ & 576.29 & 96.05 & $2.82 \mathrm{NS}$ & 0.137 & $31,683.68$ & $5,280.61$ & $4.10^{*}$ & 0.029 \\
\hline Isolate $^{\mathrm{d}}$ & $1(1)$ & 451.70 & 451.70 & $36.14 \mathrm{NS}$ & 0.105 & $2,942.24$ & $2,942.24$ & $8.50 \mathrm{NS}$ & 0.100 \\
\hline Cultivar $\times$ isolate $\mathrm{e}^{\mathrm{e}}$ & $6(6)$ & 408.40 & 68.07 & $2.16 \mathrm{NS}$ & 0.208 & $2,237.84$ & 372.97 & $1.12 \mathrm{NS}$ & 0.423 \\
\hline Year $\times$ cultivar & $5(9)$ & 170.12 & 34.03 & $1.08 \mathrm{NS}$ & 0.467 & $11,577.72$ & $1,286.41$ & $3.85^{*}$ & 0.029 \\
\hline Year $\times$ isolate & $1(2)$ & 12.50 & 12.50 & $\ldots$ & $\ldots$ & 692.21 & 346.10 & $\ldots$ & $\ldots$ \\
\hline Year $\times$ cultivar $\times$ isolate & $5(9)$ & 157.45 & 31.49 & $\ldots$ & $\ldots$ & $3,004.37$ & 333.82 & $\ldots$ & $\ldots$ \\
\hline Error & $69(98)$ & $2,654.77$ & 38.48 & $\ldots$ & $\ldots$ & $\ldots$ & $\ldots$ & $\ldots$ & $\ldots$ \\
\hline Total & $100(142)$ & $7,770.45$ & $\ldots$ & $\ldots$ & $\ldots$ & $\ldots$ & $\ldots$ & $\ldots$ & $\ldots$ \\
\hline \multicolumn{10}{|l|}{ White cultivars } \\
\hline Year & $1(2)$ & $5,724.73$ & $5,724.73$ & $\ldots$ & $\ldots$ & $40,659.76$ & $20,329.88$ & $\ldots$ & $\ldots$ \\
\hline Rep (year) & $6(9)$ & 37.82 & 6.30 & $\ldots$ & $\ldots$ & $6,449.48$ & 716.61 & $\ldots$ & $\ldots$ \\
\hline Cultivar ${ }^{\mathrm{c}}$ & 18 (19) & $1,875.00$ & 104.17 & $2.22 \mathrm{NS}$ & 0.060 & $67,409.20$ & $3,547.85$ & $4.62^{* *}$ & 0.001 \\
\hline Isolate $^{\mathrm{d}}$ & $1(1)$ & 399.66 & 399.66 & $1.50 \mathrm{NS}$ & 0.436 & $17,084.33$ & $17,084.33$ & $2.57 \mathrm{NS}$ & 0.250 \\
\hline Cultivar $\times$ isolate & 18 (19) & 740.61 & 41.15 & $1.52 \mathrm{NS}$ & 0.214 & $7,153.81$ & 376.52 & $0.81 \mathrm{NS}$ & 0.684 \\
\hline Year $\times$ cultivar ${ }^{\mathrm{e}}$ & $16(30)$ & 751.92 & 47.00 & $1.74 \mathrm{NS}$ & 0.152 & $23,031.73$ & 767.73 & $1.64 \mathrm{NS}$ & 0.090 \\
\hline Year $\times$ isolate & $1(2)$ & 266.95 & 266.95 & $\ldots$ & $\ldots$ & $13,309.68$ & $6,654.84$ & $\ldots$ & $\ldots$ \\
\hline Year $\times$ cultivar $\times$ isolate & $14(30)$ & 377.80 & 26.99 & $\ldots$ & $\ldots$ & $14,012.53$ & 467.08 & $\ldots$ & $\ldots$ \\
\hline Error & $200(300)$ & $3,018.96$ & 15.10 & $\ldots$ & $\ldots$ & $71,210.34$ & 237.37 & $\ldots$ & $\ldots$ \\
\hline Total & $275(412)$ & $13,728.98$ & $\ldots$ & $\cdots$ & $\cdots$ & $268,598.51$ & $\ldots$ & $\cdots$ & $\cdots$ \\
\hline
\end{tabular}

${ }^{a}$ Values followed by NS $=$ nonsignificant at $P=0.05, *=$ significant at $P \leq 0.05, * *=$ significant at $P \leq 0.01$.

${ }^{\mathrm{b}}$ Values in parenthesis are degrees of freedom for incidence of pink rot.

${ }^{c}$ Significance tested using year $\times$ cultivar as an error term.

d Significance tested using year $\times$ isolate as an error term.

${ }^{\mathrm{e}}$ Significance tested using year $\times$ cultivar $\times$ isolate as an error term. 
1207 (96.3\%), Itasca (96.3\%), Pike (95.6\%), Yukon Gold (93.5\%), ShepodyNL (93.1\%), and Shepody (92.3\%) had the highest incidence of infected tubers, whereas cv. Snowden (33.5\%) had the lowest incidence of infection by Pythium ultimum (Table 3), followed by cultivars FL-1867 (47.5\%) and FL-1625 (44.1\%).

Assessment of severity of leak. Differences of severity values (rot penetration) caused by the colonization of tuber tissue by the leak pathogen were similar in all the red cultivars; however, significant differences in rot penetration were found among russet and white cultivars (Table 3 ). Tuber tissue of russet cultivars such as Liberty Russet, Goldrush, and Ranger Russet were more extensively rotted than tuber tissue of
Russet Burbank and Russet Norkotah. Among the white cultivars, tubers of FL1207 followed by Itasca and Superior rotted more extensively than tubers of FL1900, FL-1867, NorValley, Yukon Gold, or Snowden (Table 3).

Assessment of the association incidence and severity of leak. Incidence and severity of leak in russet and white cultivars were highly correlated (russets: $r=$ $0.8, P=0.02$; whites: $r=0.6, P=0.004$ ). However, this relationship was not evident with some cultivars. Plotting of paired values of incidence and severity divided cultivars into several groups (Fig. 2). One group included resistant cultivars showing low incidence of infection and also less extensive rotting of tuber tissue: Snowden,

Table 3. Incidence and severity of pink rot and leak caused by Phytophthora erythroseptica and Pythium ultimum, respectively, in tubers of 34 potato cultivars $^{\mathrm{a}}$

\begin{tabular}{|c|c|c|c|c|c|}
\hline \multirow[b]{2}{*}{ Cultivars $^{b}$} & \multirow{2}{*}{$\begin{array}{c}\text { Yr tested } \\
\text { (no.) }\end{array}$} & \multicolumn{2}{|c|}{ Pink rot } & \multicolumn{2}{|c|}{ Leak } \\
\hline & & Incidence & Severity & Incidence & Severity \\
\hline \multicolumn{6}{|l|}{ Red cultivars } \\
\hline Viking & 3 & 78.0 & 38.6 & 92.6 & 23.8 \\
\hline Red LaSoda & 3 & 73.6 & 38.2 & 88.5 & 23.2 \\
\hline La Rouge & 3 & 66.4 & 37.6 & 89.0 & 22.8 \\
\hline Red Pontiac & 3 & 62.3 & 37.9 & 90.6 & 24.0 \\
\hline Dark Red Norland & 2 & 61.9 & 38.6 & 95.6 & 29.8 \\
\hline Norland & 3 & 52.2 & 36.2 & 94.8 & 27.1 \\
\hline NorDonna & 3 & 51.6 & 35.7 & 77.3 & 23.6 \\
\hline LSD & $\ldots$ & 9.6 & NS & NS & NS \\
\hline \multicolumn{6}{|l|}{ Russet cultivars } \\
\hline Russet Norkotah & 3 & 88.1 & 37.6 & 76.7 & 20.3 \\
\hline Liberty Russet & 1 & 82.5 & 45.3 & 97.5 & 30.2 \\
\hline Goldrush & 3 & 64.5 & 34.4 & 85.0 & 26.2 \\
\hline Russet Burbank-NLLR & 2 & 55.9 & 32.3 & 88.1 & 20.7 \\
\hline Russet Burbank-NL & 3 & 54.5 & 32.7 & 77.5 & 21.2 \\
\hline Russet Burbank & 3 & 50.1 & 36.0 & 73.0 & 20.4 \\
\hline Ranger Russet & 3 & 43.3 & 37.0 & 88.1 & 25.1 \\
\hline LSD & $\ldots$ & 9.2 & NS & NS & 1.6 \\
\hline \multicolumn{6}{|l|}{ White cultivars } \\
\hline Snowden & 3 & 85.3 & 34.7 & 33.5 & 18.9 \\
\hline FL-1207 & 1 & 76.9 & 36.3 & 96.3 & 32.3 \\
\hline Kennebec & 3 & 76.6 & 41.3 & 67.4 & 23.0 \\
\hline Shepody-NL & 2 & 74.7 & 35.1 & 93.1 & 26.1 \\
\hline Itasca & 3 & 66.2 & 36.6 & 96.3 & 29.9 \\
\hline FL-1625 & 3 & 65.1 & 39.9 & 44.1 & 19.7 \\
\hline FL-1867 & 2 & 64.3 & 35.3 & 47.5 & 17.7 \\
\hline FL-1879 & 3 & 63.3 & 37.9 & 76.6 & 20.8 \\
\hline Shepody & 3 & 63.1 & 38.1 & 92.3 & 26.0 \\
\hline Yukon Gold & 3 & 62.5 & 36.8 & 93.5 & 18.0 \\
\hline FL-1831 & 3 & 59.5 & 39.5 & 70.8 & 24.8 \\
\hline FL-1533 & 3 & 59.3 & 35.6 & 70.8 & 21.0 \\
\hline Superior & 3 & 58.5 & 38.9 & 97.3 & 29.4 \\
\hline NorValley & 3 & 51.3 & 41.0 & 74.7 & 18.0 \\
\hline LaChipper & 2 & 50.0 & 34.1 & 96.9 & 20.2 \\
\hline Pike & 2 & 47.8 & 33.4 & 95.6 & 25.5 \\
\hline Norchip & 3 & 47.0 & 41.2 & 82.9 & 24.0 \\
\hline FL-1833 & 2 & 45.9 & 33.7 & 79.7 & 25.2 \\
\hline Atlantic & 3 & 31.6 & 33.2 & 77.3 & 23.1 \\
\hline FL-1900 & 1 & 23.4 & $\ldots$ & 77.3 & 15.7 \\
\hline LSD & $\ldots$ & 10.0 & 2.9 & 7.3 & 1.8 \\
\hline
\end{tabular}

${ }^{\text {a }}$ Mean incidence (\%) of infection from two experiments per isolate in 1998 and one experiment in 1999 and 2000 with four replications of 10 tubers of each cultivar per replication; mean severity $(\mathrm{mm})$ of penetration of rot solely based in infected tubers; NS = not significant; $\ldots=$ missing value.

${ }^{\mathrm{b}} \mathrm{LSD}=$ least significant difference, $P=0.05$.

FL-1625, and 1867. Another group contained susceptible cultivars with a high incidence of infection accompanied with extensive rotting: Superior, Itasca, and Dark Red Norland. A third group comprised cultivars such as: Yukon Gold and LaChipper with high incidence of leak but with low tuber rot severity (Fig. 2).

\section{DISCUSSION}

Results from inoculation of tubers produced in three different locations in three consecutive years revealed that the potato cultivars evaluated in this study differed in their reaction to Phytophthora erythroseptica and Pythium ultimum. Our data indicate that most of the potato cultivars currently grown in the United States are mostly susceptible to both the pink rot and leak pathogens; however, there were cultivars that have higher levels of resistance as measured by reduced incidence and colonization of tubers. Our data, therefore, agree with previous reports on these diseases $(12,13,16,17,20)$. This high susceptibility of the current cultivars may reflect the fact that potato breeding programs have not focused on breeding for resistance to these diseases. Thus, it might be desirable for breeding purposes to survey collections of potato cultivars and lines including wild species to identify the best source of resistance. Interestingly, cv. Snowden was highly susceptible to Phytophthora erythroseptica while being the least susceptible to Pythium ultimum. Cv. Pike followed almost the same pattern. These results may indicate that a different gene or genes is involved in resistance to these two pathogens.

The susceptibility of tuber eyes to infection by Phytophthora infestans, a relative of $P$. erythroseptica, remains the same over an extended period after harvest (18). Thus, the use of zoospores of P. erythroseptica to infect eyes of whole and undamaged tubers should closely simulate how infection naturally occurs in the field. Moreover, symptoms of pink rot starting at tuber eyes in moist areas have been reported $(5,6)$. We also have observed this type of infections in our pink rot surveys in North America, particularly under heavy disease pressure (i.e., favorable temperature, 20 to $25^{\circ} \mathrm{C}$ ) and high inoculum density (31). Therefore, under these circumstances, less incidence of infection and less severe rotting of tuber tissue caused by the pink rot pathogen indicate that cultivar Atlantic has some resistance to $P$. erythroseptica; which is consistent with what was reported previously in that this cultivar has some resistance to "wet rot" (37). Cvs. LaChipper, Pike, and FL-1833 also may have some resistance to $P$. erythroseptica. Likewise, Nordonna and Norland among the red-skinned cultivars and Ranger Russet and Russet Burbank among the russet-skinned cultivars appear to have less susceptibility to $P$. erythroseptica relative 


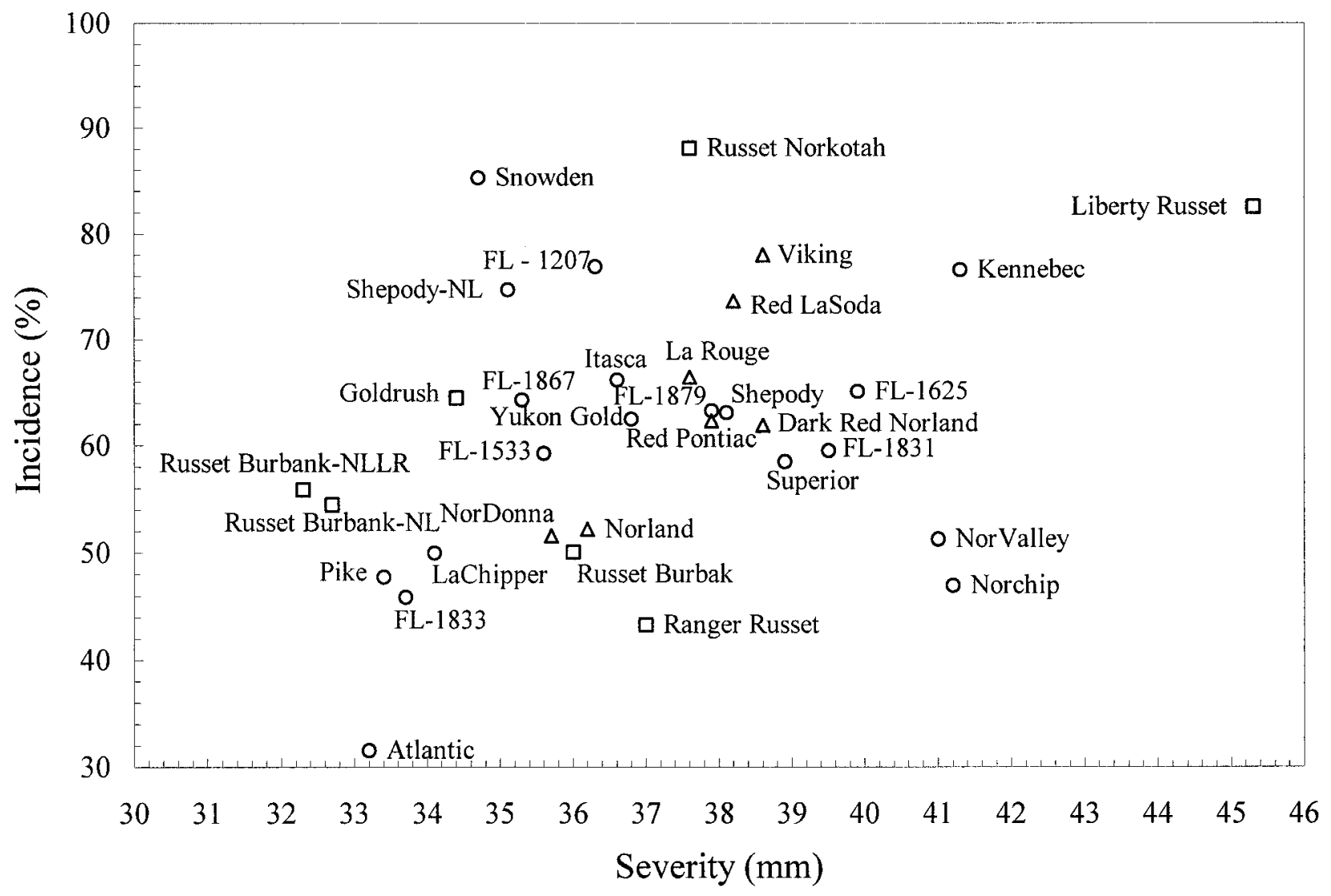

Fig. 1. Comparison of potato cultivars (red cultivars $=\triangle$, russet cultivars $=\square$, and white cultivars $=\bigcirc$ ) for resistance to Phytophthora erythroseptica based on paired values of incidence of infection (resistance to infection) and severity of rot penetration (resistance to colonization).

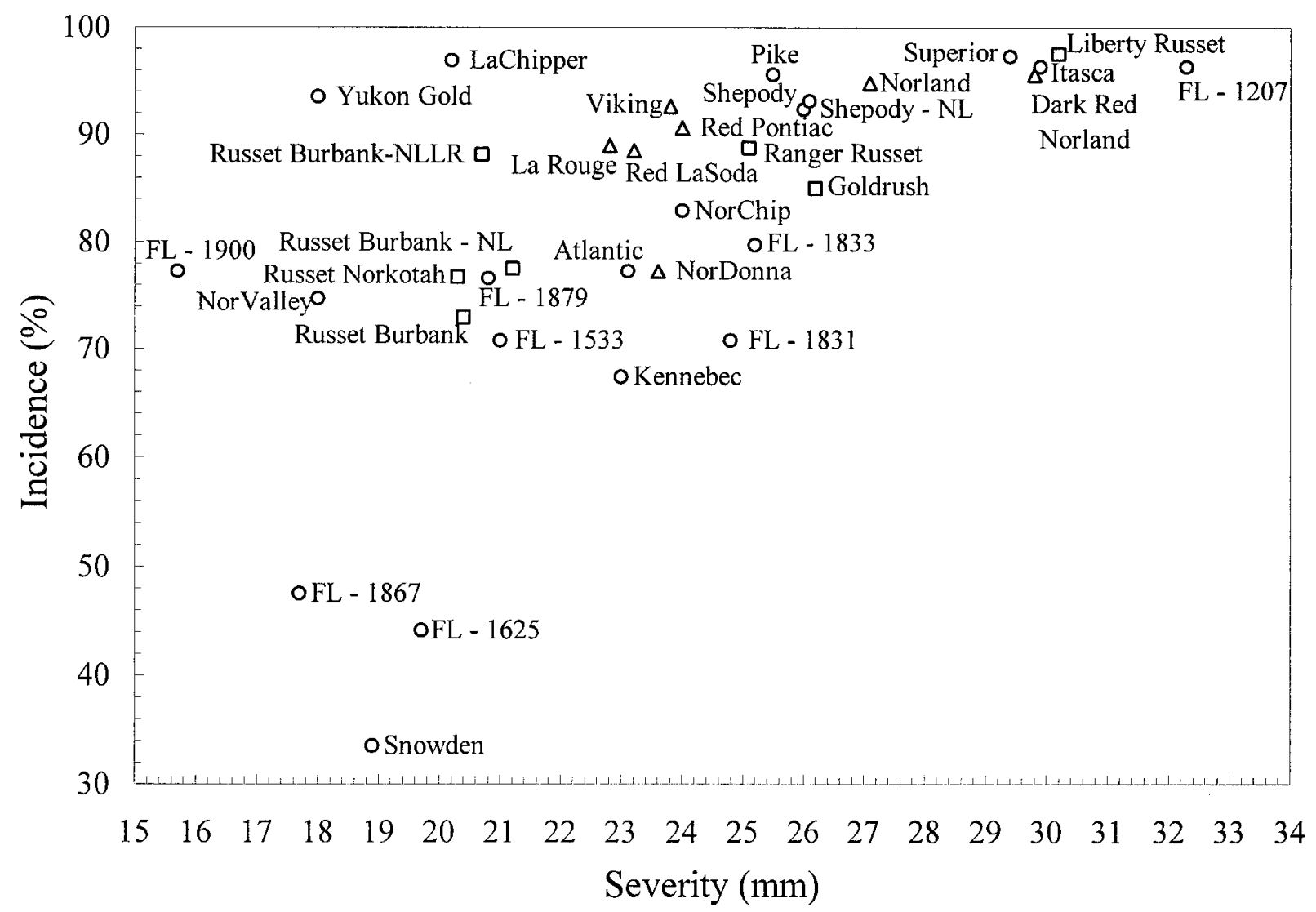

Fig. 2. Comparison of potato cultivars (red cultivars $=\triangle$, russet cultivars $=\square$, and white cultivars $=\bigcirc$ ) for resistance to Pythium ultimum based on paired values of incidence of infection (resistance to infection) and severity of rot penetration (resistance to colonization). 
to other cultivars. Our data also agree with the finding by Peters and Sturz (25) that cv. Russet Burbank is less susceptible than cvs. Goldrush and Yukon Gold to infection by $P$. erythroseptica. These three cultivars do not differ in the severity of tuber rotting, however (Table 3; Fig. 1). Cvs. Pike and Russet Burbank had been reported to be less susceptible to $P$. infestans US-8 $(9,26)$. That resistance to $P$. infestans also confers resistance to $P$. erythroseptica has not been demonstrated in potato cultivars and should be investigated further.

Pythium ultimum is incapable for penetrating the undamaged skin of the tuber (14); therefore, tuber infection by this pathogen occurs mainly through wounds and injuries caused during the harvest operations, and is compounded by temperatures above $20^{\circ} \mathrm{C}$ (32). Wounds, from minute to severe cuts, occur routinely during harvest and bin-filling operations (15). The inoculation method used here, including severe wounding and holding inoculated tubers at temperatures above $20^{\circ} \mathrm{C}$, closely approximates the natural infection conditions that exist when high levels of disease occur. Thus, it is noteworthy that cvs. Snowden, FL-1625, and FL-1867 appeared to have resistance to $P$. ultimum.
These cultivars all had less incidence of leak infection, and there was limited tuber rot. Snowden has been reported to have some resistance to Phytophthora infestans $(9,14)$. Hawkins and Harvey (14) found that cultivars in which cell walls are resistant to mechanical puncture also are resistant to leak; this characteristic should be explored in future studies involving resistance.

The relationship of incidence and severity in these two diseases, and the high correlation between incidence of infection and severity of leak (rot) with exceptions, may indicate that these traits are adequate for screening tuber resistance, with incidence being the easier and most rapid to assess. The nonsignificant correlation between incidence and severity of pink rot in russet and white cultivars should be interpreted with caution because our severity data may be due to one, two, or three infections per tuber, which can greatly affect disease severity but leave no effect on disease incidence. Future studies should address the effect of number of infection points on pink rot severity.

Our data also demonstrate that attention to cultural management practices used for leak and pink rot control is more important with some cultivars than it is with others.
For example, based on our results of disease incidence, it is obvious that it is more difficult to manage pink rot in Russet Norkotah than it is in Russet Burbank. Potato growers have experienced the same trend and the use of mefenoxam-based fungicides tends to be higher on Russet Norkotah than for Russet Burbank for this reason (unpublished data). A central component of any disease management program typically involves the use of resistant cultivars. Cultivars that are less susceptible to tuber infection by $P$. erythroseptica and Pythium ultimum could play an important role in the integrated management of pink rot and leak in potato production fields until new resistant cultivars are developed. Highly susceptible cultivars should not be planted in fields with a history of occurrence of pink rot or leak. This would be a particularly important concern in fields with wet areas or fields that are irrigated frequently. Cultivars with some resistance might be planted, but complemented with other control measures such as the use of mefenoxam-based fungicides $(23,38)$.

\section{ACKNOWLEDGMENTS}

We thank D. Peterson for technical assistance, summers helpers for assistance with the field plots, and S. Ruud and F. A. El-Samen for technical assistance with inoculations.

Table 4. Combined analysis of variance of severity and incidence of leak caused by Pythium ultimum in 34 potato cultivars ${ }^{\mathrm{a}}$

\begin{tabular}{|c|c|c|c|c|c|c|c|c|c|}
\hline \multirow[b]{2}{*}{ Sources of variation } & \multirow[b]{2}{*}{ DF } & \multicolumn{4}{|c|}{ Severity } & \multicolumn{4}{|c|}{ Incidence } \\
\hline & & SS & MS & $F$ value & $P R>F$ & SS & MS & $F$ value & $P R>F$ \\
\hline \multicolumn{10}{|l|}{ Red cultivars } \\
\hline Year (location) & 2 & $1,328.53$ & 664.26 & $\ldots$ & $\ldots$ & $4,440.32$ & $2,220.16$ & $\ldots$ & $\ldots$ \\
\hline Rep (year) & 9 & 17.66 & 1.96 & & & 652.94 & 72.55 & $\ldots$ & $\ldots$ \\
\hline Cultivar ${ }^{\mathrm{b}}$ & 6 & 592.68 & 98.78 & $2.85 \mathrm{NS}$ & 0.063 & $4,605.58$ & 767.60 & $2.02 \mathrm{NS}$ & 0.148 \\
\hline Isolates $^{c}$ & 1 & 293.72 & 293.72 & $5.39 \mathrm{NS}$ & 0.146 & 347.24 & 347.24 & $0.87 \mathrm{NS}$ & 0.450 \\
\hline Cultivar $\times$ isolate $^{\mathrm{d}}$ & 6 & 182.76 & 30.46 & $1.12 \mathrm{NS}$ & 0.413 & $1,082.69$ & 180.45 & $0.70 \mathrm{NS}$ & 0.655 \\
\hline Year $\times$ cultivar & 11 & 381.51 & 34.68 & $1.27 \mathrm{NS}$ & 0.349 & $4,174.26$ & 379.48 & $1.47 \mathrm{NS}$ & 0.265 \\
\hline Year $\times$ isolate & 2 & 108.96 & 54.48 & $\ldots$ & $\ldots$ & 801.12 & 400.56 & $\ldots$ & $\ldots$ \\
\hline Year $\times$ cultivar $\times$ isolate & 11 & 300.22 & 27.93 & $\ldots$ & $\ldots$ & $2,831.80$ & 257.44 & $\ldots$ & $\ldots$ \\
\hline Error & 111 & 521.93 & 4.70 & $\ldots$ & $\ldots$ & $5,569.56$ & 50.18 & $\ldots$ & $\ldots$ \\
\hline Total & 159 & $3,899.44$ & $\ldots$ & $\ldots$ & $\ldots$ & $25,125.90$ & $\ldots$ & $\ldots$ & $\ldots$ \\
\hline Russet cultivars & & & & & & $\ldots$ & $\ldots$ & $\ldots$ & $\ldots$ \\
\hline Year (location) & 2 & $1,915.71$ & 957.85 & $\ldots$ & $\ldots$ & $26,527.51$ & $13,263.76$ & $\ldots$ & $\ldots$ \\
\hline Rep (year) & 9 & 93.51 & 10.39 & $\ldots$ & $\ldots$ & 727.68 & 80.85 & $\ldots$ & $\ldots$ \\
\hline Cultivar ${ }^{\mathrm{b}}$ & 6 & 898.67 & 149.78 & $5.32^{* *}$ & 0.013 & $4,089.04$ & 681.51 & $1.74 \mathrm{NS}$ & 0.219 \\
\hline Isolates $^{c}$ & 1 & 261.41 & 261.41 & $3.54 \mathrm{NS}$ & 0.201 & $4,629.55$ & $4,629.55$ & $3.61 \mathrm{NS}$ & 0.198 \\
\hline Cultivar $\times$ isolate $^{\mathrm{d}}$ & 6 & 567.60 & 94.60 & $6.40^{* *}$ & 0.007 & $2,844.59$ & 474.10 & $2.36 \mathrm{NS}$ & 0.119 \\
\hline Year $\times$ cultivar & 9 & 253.61 & 28.18 & $1.91 \mathrm{NS}$ & 0.175 & $3,529.29$ & 392.14 & $1.96 \mathrm{NS}$ & 0.166 \\
\hline Year $\times$ isolate & 2 & 147.72 & 73.86 & $\ldots$ & $\ldots$ & $2,567.71$ & $1,283.86$ & $\ldots$ & $\ldots$ \\
\hline Year $\times$ cultivar $\times$ isolate & 9 & 133.02 & 14.78 & $\ldots$ & $\ldots$ & $1,804.42$ & 200.49 & $\ldots$ & $\ldots$ \\
\hline Error & 99 & 578.37 & 5.84 & $\ldots$ & $\ldots$ & $\ldots$ & $\ldots$ & $\ldots$ & $\ldots$ \\
\hline Total & 143 & $5,397.97$ & $\ldots$ & $\ldots$ & $\ldots$ & $\ldots$ & $\ldots$ & $\ldots$ & $\ldots$ \\
\hline \multicolumn{10}{|l|}{ White cultivars } \\
\hline Year & 2 & $3,702.22$ & $1,851.11$ & $\ldots$ & $\ldots$ & $36,007.65$ & $18,003.82$ & $\ldots$ & $\ldots$ \\
\hline Rep (year) & 9 & 47.77 & 5.31 & $\ldots$ & $\ldots$ & 788.33 & 87.59 & $\ldots$ & $\ldots$ \\
\hline Cultivar ${ }^{\mathrm{b}}$ & 19 & $6,357.77$ & 334.62 & $4.99^{* *}$ & 0.001 & $121,984.14$ & $6,420.22$ & $6.51^{* *}$ & 0.001 \\
\hline Isolates $^{c}$ & 1 & $1,195.35$ & $1,195.35$ & 4.49 NS & 0.168 & $2,121.85$ & $2,121.85$ & $3.47 \mathrm{NS}$ & 0.204 \\
\hline Cultivar $\times$ isolate $^{\mathrm{d}}$ & 18 & 466.08 & 25.89 & $0.81 \mathrm{NS}$ & 0.678 & $6,974.27$ & 387.46 & $1.70 \mathrm{NS}$ & 0.102 \\
\hline Year $\times$ cultivar $^{\mathrm{d}}$ & 28 & $1,879.42$ & 67.12 & $2.09^{*}$ & 0.028 & $27,618.41$ & 986.37 & $4.32^{* *}$ & 0.001 \\
\hline Year $\times$ isolate & 2 & 532.57 & 266.29 & $\ldots$ & $\ldots$ & $1,223.89$ & 611.95 & $\ldots$ & $\ldots$ \\
\hline Year $\times$ cultivar $\times$ isolate & 28 & 898.44 & 32.09 & $\ldots$ & $\ldots$ & $6,393.54$ & 228.34 & $\ldots$ & $\ldots$ \\
\hline Error & 276 & $1,821.05$ & 6.62 & $\ldots$ & $\ldots$ & $29,385.78$ & 106.47 & $\ldots$ & $\ldots$ \\
\hline Total & 383 & $18,230.09$ & $\ldots$ & $\ldots$ & $\ldots$ & $246,998.27$ & $\ldots$ & $\ldots$ & $\ldots$ \\
\hline
\end{tabular}

a Values followed by: $\mathrm{NS}=$ nonsignificant at $\mathrm{P}=0.05, *$ significant at $\mathrm{P}=\leq 0.05, * *=$ significant and $\mathrm{P}=\leq 0.01$.

${ }^{\mathrm{b}}$ Significance tested using year $\times$ cultivar as an error term.

c Significance tested using year $\times$ isolate as an error term.

${ }^{\mathrm{d}}$ Significance tested using year $\times$ cultivar*isolate as an error term. 


\section{LITERATURE CITED}

1. Blodgett, E. C. 1945. Water rot of potatoes. Plant Dis. Rep. 29:124-126.

2. Blodgett, E. C., and Ray, W. W. 1945. Leak caused by Pythium debaryanum Hesse, produces typical shell rot of potatoes in Idaho. Am. Potato J. 22:250-253.

3. Bonde, R. 1938. The occurrence of pink rot and wilt in Maine. Plant Dis. Rep. 22:460.

4. Boothroyd, C. W. 1951. Pink rot of potato found in New York state. Plant Dis. Rep. 35:55.

5. Cairns, H., and Muskett, A. E. 1933. Pink rot of potato. Ann. Appl. Biol. 20:381-402.

6. Cairns, H., and Muskett, A. E. 1939. Phytophthora erythroseptica Pethyb. in relation to its environment. Ann. Appl. Biol. 26:470-480.

7. Carmer, S. G., Nyquist, W. E., and Walker, W. M. 1989. Least significant differences for combined analysis of experiments with two-or three-factor treatment designs. Agron. J. 81:665-672.

8. Carrol, R. B., and Sasser, M. 1974. An outbreak of potato pink rot in Delaware. Plant Dis. Rep. 58:443-445.

9. Douches, D. S., Kirk, W. W., Jastrzebski, K. K., Long, C., and Hammerschmidt, R. 1997. Susceptibility of potato varieties and advanced breeding lines (Solanum tuberosum L.) to Phytophthora infestans (Mont.) de Bary in greenhouse screenings. Am. Potato J. 74:75-86.

10. Fernandez-Northcote, E. N., Huapaya R., E., and Torres M., H. 1972. La podredumbre rosada de la papa; busqueda de fuentes de resistencia en tuberculos (Pink rot of potatoes; screening for tuber resistance). Fitopatologia $6: 18-27$.

11. Gomez, A. A., and Gomez, K. A. 1984. Statistical Procedures for Agricultural Research, 2nd ed. Wiley, New York.

12. Goss, R. W. 1949. Pink rot of potato caused by Phytophthora erythroseptica Pethyb. Univ. Nebr. Coll. Agric. Agric. Exp. Stn. Res. Bull. 160, Lincoln.

13. Hawkins, L. A. 1916. The disease of potatoes known as leak. J. Agric. Res. 6:627-641.

14. Hawkins, L. A., and Harvey, R. B. 1919. Physiological study of the parasitism of $P y$ thium debaryanum Hesse on the potato tuber.
J. Agric. Res. 18:275-303.

15. Hudson, D. E., and Orr, P. H. 1977. Incidence of mechanical injury to potatoes during certain storage-related handling operations in the Red River Valley production area. Am. Potato J. 54:11-21.

16. Jones, W. 1935. Soft rot of potatoes caused by Pythium ultimum Trow. Sci. Agric. 15:402410.

17. Jones, W. 1945. Pink rot disease of potatoes in British Columbia. Sci. Agric. 25:597-600.

18. Lapwood, D. H. 1967. Laboratory assessment of the susceptibility of potato tubers to infection by blight (Phytophthora infestans). Eur. Potato J. 10:127-132.

19. Lapwood, D. H., Read, P. J., and Spokes, J. 1984. Methods for assessing the susceptibility of potato tubers of different cultivars to rotting by Erwinia carotovora subspecies atroseptica and carotovora. Plant Pathol. 33:13-20.

20. Lennard, J. H. 1980. Factors influencing the development of potato pink rot (Phytophthora erythroseptica). Plant Pathol. 29:80-86.

21. Lonsdale, D., Cunliffe, C., and Epton, H. A. S. 1980. Possible routes of entry of Phytophthora erythroseptica Pethyb. And its growth within potato plants. Phytopathol. Z. 97:109-117.

22. Love, S. L. 1999. Founding clones, major contribution ancestors, and exotic progenitors of prominent North American potato cultivars. Am. J. Potato Res. 76:263-272.

23. Mulrooney, R. P. 1982. Evaluation of ridomil for pink rot and leak control, 1981. Fungic. Nematicide Test 37:78.

24. Perez, W., Gutarra, L., and French, E. 1994. Pythium ultimum Trow. causante de pudricion acuosa en tuberculos de papa en el Peru. Fitopatologia 29:191-196.

25. Peters, R. D., and Sturz, A. 2001. A rapid technique for the evaluation of potato germ plasm for susceptibility to pink rot. Plant Dis. 85:833-837.

26. Peters, R. D., Platt, H. W., Hall, R., and Medina, M.1999. Variation in aggressiveness of Canadian isolates of Phytophthora infestans as indicated by their relative abilities to cause potato tuber rot. Plant Dis. 83:652-661.

27. Pethybridge, G. H. 1913. On the rotting of potato tubers by a new species of Phy tophthora having a method of sexual reproduction hitherto undescribed. Sci. Proc. R. Dublin Soc. 13:529-565.

28. Priou, S., Triki, M. A., Elmahjoub, M., and Fahem, M. 1997. Assessing potato cultivars in Tunisia for susceptibility to leak caused by Pythium aphanidermatum. Potato Res. 40:399-406.

29. Salas, B., Secor, G. A., and Gudmestad, N. C. 1997. Susceptibility of potato tubers to infection by Phytophthora erythroseptica zoospores. (Abstr.) Phytopathology 87:S84.

30. Salas, B., Secor, G. A., Taylor, R. J., and Gudmestad, N. C. 2000. Evaluation of potato genotypes for resistance to pink rot and leak. (Abstr) Am. J. Potato Res. 77:418.

31. Salas, B., Stack, R. W., Secor, G. A., and Gudmestad, N.C. 2000. Effect of temperature wounding and inoculum density on the development of pink rot caused by Phytophthora erythroseptica. Plant Dis. 84:1327-1333.

32. Secor, G. A., and Gudmestad, N. C. 1999. Managing fungal diseases of potato. Can. J. Plant Pathol. 21:213-221.

33. Stack, R. W., Salas, B., Gudmestad, N. C., and Secor, G. A. 1994. Pink rot susceptibility of potato cultivars and experimental lines, 1992. Biol. Cult. Tests 9:69.

34. Stamps, D. J., Waterhouse, G. M., Newhook, F. J., and Hall, G. S. 1990. Revised tabular key to the species of Phytophthora. Mycological Papers, No. 162. CAB Int Mycol. Inst., Wallingford, Oxon, UK.

35. Van der Plaats-Niterink, A. J. 1981. Monograph of the genus Pythium. Stud. Mycol. 21:1-242.

36. Vujicic, R., and Colhoun, J. 1966. Asexual reproduction in Phytophthora erythroseptica. Trans. Br. Mycol. Soc. 49:245-254.

37. Webb, R. E., Wilson, D. R., Shumaker, J. R., Graves, B., Henninger, M. R., Watts, J., Frank, J. A., and Murphy, H. J. 1978. Atlantic: A new potato variety with high solids, good processing quality, and resistance to pests. Am. Potato J. 55:141-145.

38. Wicks, T. J., Davoren, C. W., and Hall, B. H. 2000. Fungicidal control of Phytophthora erythroseptica: The cause of pink rot on potato. Am. J. Potato Res. 77:233-240. 